\title{
Tourist Satisfaction and Service Delivery at Nech Sar National Park of Ethiopia
}

\author{
Bililign Zafu1, Molla Mekonnen Alemu² \\ ${ }^{1}$ Nech Sar National Park, Arba Minch, Ethiopia \\ ${ }^{2}$ University of Leicester, Leicester, UK \\ Email: bilzafu@gmail.com
}

How to cite this paper: Zafu, B. and Alemu, M.M. (2016) Tourist Satisfaction and Service Delivery at Nech Sar National Park of Ethiopia. Open Access Library Journal, 3: e3230.

http://dx.doi.org/10.4236/oalib.1103230

Received: November 14, 2016

Accepted: December 5, 2016

Published: December 8, 2016

Copyright $\odot 2016$ by authors and Open Access Library Inc.

This work is licensed under the Creative

Commons Attribution International

License (CC BY 4.0).

http://creativecommons.org/licenses/by/4.0/

\begin{abstract}
The tourism industry is contributing a lot for the economic development of many countries worldwide along with its contribution for the development of livelihoods. Tourist satisfaction on service delivery of Nech Sar National Park is examined in the present study. Primary data were collected from foreign and domestic tourist and different workers of the park. Accordingly, a total of 167 (52\% men) participated for the data collection. Qualitative and quantitative data were collected through questionnaires, interviews, observations and document analysis. Based on the findings of the study, it was found out that landscape, environment, cost, and working hours were among the factors which satisfied visitors and the visitors were also dissatisfied by infrastructure, service offered at night time in camp sites, and deforestation.
\end{abstract}

\section{Subject Areas}

Environmental Economics, Marketing

\section{Keywords}

Tourist, Satisfaction, Nech Sar National Park

\section{Introduction}

Tourist satisfaction is generated by comparing the expectation of customers before and after a service. If the service or product doesn't meet the expectation, it will result dissatisfaction of tourists. Satisfaction on the other hand will be created as a result of a positive feeling between pre-travel expectations and the experience after the travel. Thus, if the experience of visitor's creates a feeling of gratification, then satisfaction will be created. Tourist's satisfaction has two major aspects: the first is in relation to the expectation of the tourists before ahead of the travel and the second dimension is validation 
of the rendered services after the travels of the tourist. In simple terms, tourist satisfaction is a direct result of tourist expectation and the perceived value after the visit [1].

The World Bank [2] contends that, the amount tourists spend and their satisfaction on a site are directly related to the quality of facilities and services at touristic sites. On site information center, background history, handcraft centers, public toilets, mini and super markets, banks, restaurants and accommodation are among the facilities which will impact the level of satisfaction. Even though, one has to be mindful of not over commercializing some sites, availing a base level of facilities can help to intensify a fair level of tourism spending in an area.

In countries like Ethiopia, where there is still a challenge in terms of basic infrastructure to ease the tourism sector, paving the way to increase tourism spending through establishment of appropriate facilities in the touristic sites will have a paramount importance in increasing the revenue from the industry. This will also help to capacitate local communities through livelihoods development opportunities coupled with local economic development.

Nech Sar national park is one of the earliest national parks in Ethiopia. It was established in 1974 as a result of its natural beauty and a large number of wild animals. The park is situated on the floor of the Great Rift Valley in Southern Nations and Nationalities Regional State of Ethiopia. The National Park straddles the narrow piece of land separating Lake Chamo and Lake Abaya both of which are located in the craters of ancient volcanoes. The eastern border of the park extends to include the plains at the foothills of the spectacular Amaro Mountains. In the far eastern part of the park hot springs bubble to the surface.

The flow of both domestic and foreign tourists has shown a remarkable increase in the past 15 years. According to the park's tourist and revenue data, the number of visitors has increased from 1047 in 1994/95 to 18,730 in 2011/12 and to 37,639 in 2015/16. Correspondingly, the revenue has increased from 27,185 Birr in 1994/95 to 1,333,459 in 2009/1010 (Table 1). This information may seem very low as compared to other African park's performance, however, from domestic Park's point of view, the progress is very promising.

Even though, the park has several tourist attraction sites with high number of plant and animal species, viewpoints and camp sites, visitors' satisfaction and the service delivery have never been assessed so far. To develop the tourism potential and capacitate its contribution to reduce poverty and underdevelopment in the surrounding society of the park and to increase its contribution for national growth, assessing the satisfaction of tourists in Nech Sar National Park is of great necessity. Therefore, the present study is aimed at assessing the level of tourist satisfaction and the services delivered in their stay in Nech Sar National Park.

\section{Objectives}

The overall objective of this study is to assess tourist satisfaction and service delivery of Nech Sar National Park. 
Table 1. Tourist or visitors flow and revenue of NNP.

\begin{tabular}{|c|c|c|c|c|}
\hline Year & $\begin{array}{l}\text { Foreign } \\
\text { Tourists }\end{array}$ & $\begin{array}{c}\text { Domestic } \\
\text { Tourists }\end{array}$ & $\begin{array}{c}\text { Total } \\
\text { Tourists flow }\end{array}$ & $\begin{array}{c}\text { Revenue } \\
\text { obtained } \\
\text { (Ethiopian Birr) }\end{array}$ \\
\hline 1994 & 447 & 600 & 1047 & 27,185 \\
\hline 1995 & 713 & 885 & 1598 & 42,181 \\
\hline 1996 & 2241 & 1081 & 3322 & 60,036 \\
\hline 1997 & 1035 & 999 & 2034 & 54,029 \\
\hline 1998 & 1201 & 1286 & 2487 & 66,712 \\
\hline 1999 & 1275 & 1281 & 2556 & 68,811 \\
\hline 2000 & 1113 & 1066 & 2179 & 58,362 \\
\hline 2001 & 1163 & 1017 & 2180 & 153,255 \\
\hline 2002 & 1700 & 1329 & 3029 & 222,610 \\
\hline 2003 & 2049 & 2396 & 4445 & 234,813 \\
\hline 2004 & 1703 & 1716 & 3419 & 265,477 \\
\hline 2005 & 1703 & 1716 & 3419 & 265,477 \\
\hline 2006 & 5113 & 2328 & 7441 & 639,714 \\
\hline 2007 & 7267 & 8528 & 15,795 & 695,419 \\
\hline 2008 & 8112 & 12,854 & 20,966 & 838,098 \\
\hline 2009 & 8992 & 9607 & 18,599 & 996,593 \\
\hline 2010 & 10,261 & 8469 & 18,730 & $1,033,459$ \\
\hline 2011 & 11,660 & 10,049 & 21,209 & $1,331,075$ \\
\hline 2012 & 11,227 & 10,540 & 20,417 & $1,169,345$ \\
\hline 2013 & 11,321 & 10,867 & 23,588 & $1,179,625$ \\
\hline 2014 & 11,731 & 13,819 & 24,917 & $1,332,170$ \\
\hline 2015 & 10,328 & 17,476 & 27,804 & $1,236,640$ \\
\hline Total & 112,355 & 119,909 & 231,181 & $11,971,086$ \\
\hline
\end{tabular}

\section{Methodology}

\subsection{Background of the Study Area}

The research is conducted in Arba Minch Town at Nech-Sar National Park. Arba Minch Town is one of the 22 reform town in the Southern Nation, Nationalities and Peoples Regional State. It is the center of Arba Minch Zuria District and GamoGofa Administrative Zone. The town is situated at $505 \mathrm{Km}$ and $275 \mathrm{Km}$ away from Addis Ababa and Hawassa respectively. Arba Minch Town is located at $06^{\circ} 05^{\prime} \mathrm{N}$ Latitude and $37^{\circ} 38^{\prime} \mathrm{E}$ Longitudes and lies between $1200 \mathrm{~m} / 1450 \mathrm{~m}$ above sea level and have an area of 5557 hectares or 55.57 Square $\mathrm{Km}$. The town is bounded in the north, northeast and east by Lake Abaya and in the South by Lake Chamo and in the west with the Gennta massive hills. The total population of the town is 78,879 [3] and the annual population Growth 
rate is found to be $4.8 \%$ and its density is $13 / \mathrm{Km}$ Square. Arba Minch Town is embraced by Nech Sar National Park and many others tourist attraction area. The park is found right after the eastern edge of Arba Minch town, at about $510 \mathrm{Km}$ south of Addis Ababa and $270 \mathrm{Km}$ from Hawassa. The park lies within the floor of the Great Rift Valley and extends from $5^{\circ} 51^{\prime} \mathrm{N}$ to $6^{\circ} 50^{\prime} \mathrm{N}$ and from $37^{\circ} 32^{\prime} \mathrm{E}$ to $37^{\circ} 48^{\prime} \mathrm{E}$ with an elevation varying between 1108 and 1650 above sea level. It covers an area of $514 \mathrm{Km}$ of which $85 \%$ is land and $15 \%$ is water (shores of Lake Abaya from the north and Lake Chamo in the south) [3] [4] (Figure 1).

\subsection{Data Collection and Analysis}

To select tourists for this study the research tried to observe the trend of the flow for both domestic and foreign tourists for the last two years. Accordingly the average number of visitors coming to the park per month is around 850 for foreign tourists and 674 for domestic tourists. Therefore, 85 foreign 67 domestic tourists were selected using

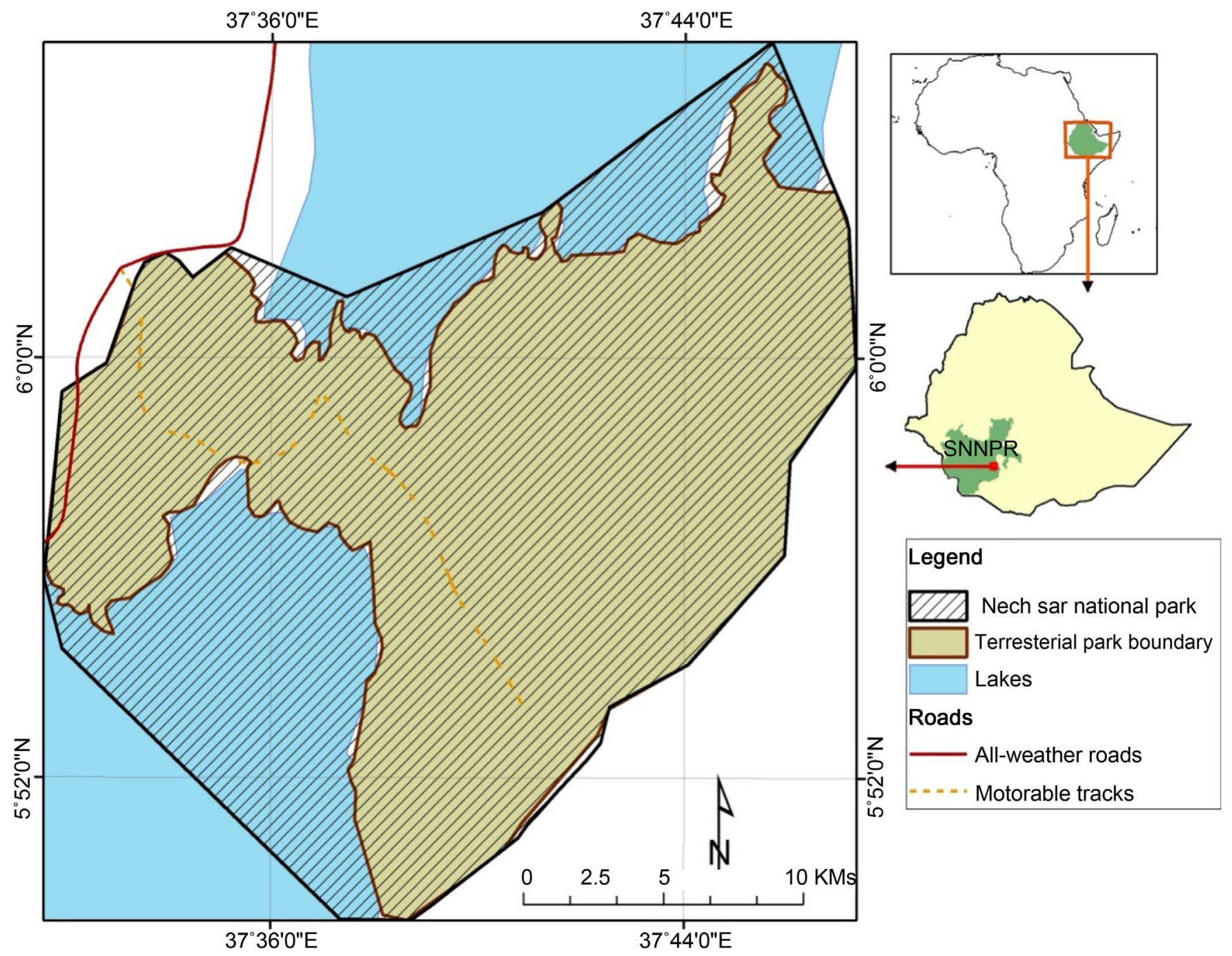

Figure 1. Location map of Nech Sar national park [5]. 
quota sampling to be participants in this study. 15 participants were also selected from the employees of the park so as to solicit information. The total number of participants in this research was 167 ( $52 \%$ male).

Information was obtained directly from participants using three data gathering tools. These were questionnaire, interview and observation. The questionnaire primarily was used to obtain information from domestic and foreign tourists regarding the satisfaction with the service rendered by the park. Interviews were employed to obtain information from the workers of the park regarding the quality of service in the park and their ideas regarding customer satisfaction. Observation was conducted by the researcher regarding the overall conditions in the park.

Secondary information was also obtained as a supplementary tool to support the primary sources. Document analysis of current reports, program of the organization, different types of publications were used in this regard. Furthermore, customers' feedback from suggestion boxes was also reviewed.

Both quantitative and qualitative techniques of data analysis were used. Quantitative analysis was employed to analyze the data obtained through questionnaires. In this regard the obtained information was tabulated and analyzed through frequencies and percentages. Qualitative techniques were used to analyze the data obtained through interviews, semi-structured observation and document analysis. Statements and narrations were used to analyze the obtained information through words and from documents. Necessary interpretations made in line with the objectives of the study.

\section{Results and Discussion}

\subsection{Tourist Satisfaction}

Tourist satisfaction is considerably linked to customer loyalty, continual visits and a positive social communication on the visited site [6]. Dorfman [7] endeavored to solidify the definition of satisfaction from recreational camping perspectives. He states that "satisfaction level are maximized when aspiration (desirability) equals perception but only when the desirability is high for that condition. Desirability for conditions could directly relate back to the social identity theory and the need for the personal distinctiveness".

When tourists are satisfied on the services rendered to them, the service providers will be recognized for their efficient service delivery. The satisfaction of tourists is usually dependent on the extent and level of individual efforts and expectations. Cardoza [8] mentioned as "customer effort is any physical, mental or monetary resource expended by the costumer in the acquisition of a service or product". Visitors will have their own perception and image before they ever travel to the site.

Among others expectations of the tourists is the motivational force to ignite the interest to visit particular touristic locations. Therefore, if the customer effort is on the high side and high expectations are achieved then customer satisfaction is likely to be materialized. On the other hand, high levels of expectation that end up in getting a low value experience will result in low levels of customer satisfaction, irrespective of the 
level of customer's effort. This kind of situation where high value expectations met low level experience, it is known as the dissonance levels in tourists. Therefore, service providers should be able to offer the actual information of touristic destinations so that unnecessary expectations can be avoided by the visitors. It is also crucial to be mindful of the fact that, sound tourist experiences can be achieved as a result of a business that knows the products, services, their customers and their own employees at hand [9].

\subsection{Service Quality}

Service quality is not a function of how much something costs but, rather, how well it meets the expectations of those who purchase it. Lewis and Booms [10] also mentioned that "in the service industry, definitions of service quality focus on meeting customers" needs and requirements, and how well the service delivered meets the customer expectations".

Service quality can thus be defined as "the difference between customer expectation of service and perceived service)". If the customer expectations are higher than performance, then the customer may experience lesser satisfaction that will result for the dissatisfaction of the customer [11] [12].

Parasurman et al. [13] also defined service quality as "the degree and direction of discrepancy between costumers' perception and costumer, and perceived service quality as the gap between costumer's expectations and perceptions, as the measurement of service quality. Thus, the smaller the gap, the better the service quality provided, and the greatest the customer satisfaction".

Gronoos [14] also mentioned that, the apparent quality service is directly linked with the contrast between expected services with the actual perceived services and there for it is the result of a comparative valuation. For this kind of cases Sweeney and Armstrong [15], utilized the conjoint analysis technique so as to assess the tradeoff functions in the perspectives of different services, and found that low prices have contributed negatively to expectations on the quality of the service but positively to service selection.

\subsection{Attributes or Factors and Their Dimension on Customer (Tourist) Satisfaction with Service Performance of the Nech Sar National Park}

In order to identify and examine tourist (customer) satisfaction attributes and their dimension related with service performance of Nech Sar National Park different question were administered which focuses on the major factor (attributes) and their level of degree that affect tourist or customer satisfaction. The summary of the responses is put forward in Table 2 .

Based on the analysis on satisfaction of the tourists with service performance of NNP, the results of Table 2 indicates that the tourists were good and highly satisfied on provision of service right at the first time (55.2\% respondent); empathy; contact with nature best reaction of the landscape, environment, lakes and the wild life which $100 \%$ of the respondent agree and $100 \%$ of the respondent were very much satisfied on the working hours which are flexible and convenient and the price or cost that they considered not expensive. 
Table 2. Attributes and their dimension on tourist satisfaction.

\begin{tabular}{|c|c|c|c|c|c|c|c|c|c|c|c|}
\hline \multirow{3}{*}{ No } & \multirow{3}{*}{$\begin{array}{l}\text { Attributes (factors) related to } \\
\text { service performance of NNP }\end{array}$} & \multicolumn{10}{|c|}{$\begin{array}{l}\text { Percentage of Satisfaction from the total } \\
\text { Respondents ( } 152 \text { tourist) }\end{array}$} \\
\hline & & \multicolumn{2}{|c|}{ Very low } & \multicolumn{2}{|c|}{ Low } & \multicolumn{2}{|c|}{ Undecided } & \multicolumn{2}{|c|}{ Good } & \multicolumn{2}{|c|}{ Very good } \\
\hline & & No. & $\%$ & No. & $\%$ & No. & $\%$ & No. & $\%$ & No. & $\%$ \\
\hline 1 & $\begin{array}{l}\text { They have modern looking } \\
\text { equipment and new technology }\end{array}$ & 52 & 34.2 & 65 & 42.7 & 0 & 0 & 35 & 23.1 & 0 & 0 \\
\hline 2 & Appealing office décor & - & - & 101 & 66.4 & 10 & 6.6 & 41 & 27 & - & - \\
\hline 3 & Employees look clean \& tidy & - & - & 44 & 30 & 13 & 8.5 & 95 & 62.5 & - & - \\
\hline 4 & $\begin{array}{l}\text { The material elements and the } \\
\text { documents that have to do with } \\
\text { service (destination, lodgings, } \\
\text { visualizing) are visually appealing }\end{array}$ & 93 & 61.2 & 39 & 25.6 & 10 & 6.6 & 10 & 6.6 & - & - \\
\hline 5 & $\begin{array}{l}\text { All the promised tasks and explained by } \\
\text { the office well performed and perfect }\end{array}$ & 53 & 35 & 46 & 30.2 & - & - & 53 & 34.8 & & \\
\hline 6 & $\begin{array}{l}\text { When the customer (tourist) has a } \\
\text { problem they show a sincere } \\
\text { interest to solve it }\end{array}$ & - & - & - & - & 27 & 17.6 & 102 & 67.2 & 23 & 15.2 \\
\hline 7 & $\begin{array}{l}\text { Provision of service right the first time } \\
\text { (first impression) }\end{array}$ & - & - & 25 & 16.5 & 8 & 5.3 & 35 & 23 & 84 & 55.2 \\
\hline 8 & They habitually perform good service & 33 & 21.7 & 40 & 26.3 & - & - & 79 & 51.9 & - & - \\
\hline 9 & $\begin{array}{l}\text { They insist on making no mistakes in } \\
\text { their document }\end{array}$ & - & - & 12.7 & 7.9 & 25 & 16.4 & 100 & 65.7 & 15 & 10 \\
\hline 10 & Telling when service to be completed & - & - & - & - & - & - & 152 & 100 & - & - \\
\hline 11 & Prompt service & - & - & 152 & 100 & - & - & - & - & 8 & \\
\hline 12 & Employees are always willing to help & & & & & & & & & & \\
\hline 13 & $\begin{array}{l}\text { When there is a problem, } \\
\text { there is always a quick response }\end{array}$ & - & - & 68 & 44.7 & - & - & 84 & 55.3 & - & - \\
\hline 14 & $\begin{array}{l}\text { The behavior of employees installs } \\
\text { confidence in their customer (Tourist) }\end{array}$ & - & - & 33 & 21.7 & 17 & 11.2 & 66 & 43.4 & 36 & 23.7 \\
\hline 15 & $\begin{array}{l}\text { You feel safe in your } \\
\text { transaction with the NNP }\end{array}$ & - & - & - & - & - & - & - & - & 152 & - \\
\hline 16 & $\begin{array}{l}\text { Employees are consistently courteous } \\
\text { with customer }\end{array}$ & - & - & - & - & - & - & 80 & 52.6 & 72 & 47.4 \\
\hline 17 & $\begin{array}{l}\text { Employees have sufficient knowledge, } \\
\text { and capacity on their job service and } \\
\text { about NNP detail explanation }\end{array}$ & 66 & 43.4 & 80 & 52.6 & - & - & 6 & 4 & - & - \\
\hline 18 & $\begin{array}{l}\text { The working hours are } \\
\text { flexible and convenient }\end{array}$ & - & - & - & - & - & - & 65 & 42.7 & 87 & 57.3 \\
\hline 19 & Personal attention by employees & - & - & - & - & - & - & 152 & 100 & - & - \\
\hline 20 & $\begin{array}{l}\text { The employees understand the specific } \\
\text { needs of their customer }\end{array}$ & 80 & 52.6 & 42 & 27.6 & 10 & 6.6 & 20 & 13.2 & - & - \\
\hline 21 & Sufficient resources to offer good service & 25 & 16.4 & 127 & 83.6 & - & - & - & - & - & - \\
\hline
\end{tabular}




\section{Continued}

\begin{tabular}{|c|c|c|c|c|c|c|c|c|c|c|c|}
\hline 22 & $\begin{array}{l}\text { Adequate capacity to } \\
\text { satisfy customer's needs }\end{array}$ & 75 & 49.3 & 40 & 26.3 & - & - & 37 & 24.4 & - & - \\
\hline 23 & $\begin{array}{c}\text { Promotion strategies and } \\
\text { implementation about NNP }\end{array}$ & 75 & 49.3 & 32 & 21.1 & - & - & 45 & 29.6 & - & - \\
\hline 24 & Responsiveness & - & - & 64 & 42.1 & - & - & 88 & 57.9 & - & - \\
\hline 25 & Reliability & & & 38 & 25 & 20 & 13.1 & 94 & 61.9 & - & - \\
\hline 26 & Empathy & - & - & - & - & - & - & 60 & 39.5 & 92 & 60.5 \\
\hline 27 & Tangibility & 30 & 19.7 & 30 & 19.7 & 30 & 19.7 & 62 & 40.9 & - & - \\
\hline 28 & Easy to access & - & - & 69 & 45.4 & - & - & 83 & 54.6 & - & - \\
\hline 29 & Expensive & - & - & - & - & - & - & 100 & 65.8 & 52 & 34.2 \\
\hline 30 & $\begin{array}{l}\text { Peace and quiet too much traffic, too } \\
\text { many people and noise }\end{array}$ & - & - & - & - & - & - & 152 & 100 & - & - \\
\hline 31 & $\begin{array}{l}\text { Contact with nature, landscape, } \\
\text { environment, \& tourist } \\
\text { attraction to see (historic site) }\end{array}$ & - & - & - & - & - & - & 102 & 67.1 & 50 & 32.9 \\
\hline 32 & $\begin{array}{l}\text { Infrastructure-road, } \\
\text { bridge (Inside the park) }\end{array}$ & 97 & 63.8 & 55 & 36.2 & - & - & - & - & - & - \\
\hline 33 & $\begin{array}{l}\text { Night life-arrangement for } \\
\text { destination-service offer } \\
\text { on } 2 \text { camping sites }\end{array}$ & 111 & 73 & 41 & 27 & - & - & - & - & - & - \\
\hline 34 & $\begin{array}{l}\text { Easy to get information and } \\
\text { available need by the customer }\end{array}$ & - & - & 69 & 45.4 & - & - & 83 & 54.6 & - & - \\
\hline 35 & Facilities to children and elders & 122 & 80.3 & 30 & 19.7 & - & - & - & - & - & - \\
\hline 36 & $\begin{array}{l}\text { Unwillingness to hear } \\
\text { advice and comment }\end{array}$ & - & - & 41 & 26.9 & - & - & 111 & 73.1 & - & - \\
\hline 37 & $\begin{array}{l}\text { Adequate communication } \\
\text { skills (language \& others) }\end{array}$ & - & - & 42 & 27.6 & - & - & 100 & 65.7 & 10 & 6.7 \\
\hline & Average & & 15.4 & & 24.1 & & 2.87 & & 40.3 & & 9.7 \\
\hline
\end{tabular}

The level of satisfaction that has found low and very low were in the following aspects: $100 \%$ of the respondent got very low and low satisfaction on the road facilities inside the park; nightlife on 2 camp site service offer, employees knowledge, capacity on service, and communication skill, and sufficient resource to offer good services. An average and in general as Table 2 shows, from 37 attributes or factors that are related to service performance of NNP identified by the respondents, $39.9 \%$ of the respondent's satisfaction were low and very low and $40.3 \%$ were satisfied well.

\subsection{The Most Important Variables That Affect Tourist Overall Satisfaction in the Study Area}

Studies on identifying and measuring the most determinant attributes that affect consumer satisfaction which emanates and related directly from service performance ren- 
dered by Nech Sar National Park indicates only the single dimension of tourists satisfaction. Therefore, the study also considered other variables on the services provided by other parties of the tourism chain. Accordingly, information on accommodation, getting money with a credit card, food and drinks, services of travel agents, climate, expensiveness of services, sport facilities, pollution, services at the airport, and other major and important factors which are not related with the service performance of Nech Sar National Park was obtained from selected respondents and the result was analyzed in Table 3.

As Table 3 indicates $85 \%$ of the respondents got good to high satisfaction regarding cost delivered to food and accommodation. Most of the tourists are satisfied on the access and opportunity to shopping, taking pictures, peace and quietness of the destination. The services rendered by souvenir shoppers got low and very low level of satisfaction which might be related to the language barriers.

Many empirical studies have showed that the tour leader is a crucial factor in achieving customer satisfaction. Chamg \& Bawie, [16] also stated that it is the tour guide (tour leader) who sells the next tour (Figure 2 and Figure 3 ).

\subsection{Tourist Dissatisfaction Factors and Causes at the Study Area}

Understanding the level of dissatisfaction, displeasure or negative impressions on a given service can help to generate effective and necessary tools in finding out how a company or tourism destination is performing. This will also help to improve the service that is being offered by the different actors. Moreover, there is no one to one correspondence between satisfaction and dissatisfaction, suggesting that the attributed or sources that generate satisfaction are not the same as those that generate dissatisfaction. For this reason, the study of dissatisfaction is believed to be complementary to the study of satisfaction. Based on the above fact the reaction of the respondents is summarized as follows.

On prominent factors that causes the dissatisfaction of tourists in NNP as Table 4 indicates are, the poor road facilities and deforestation. Cattle grazing with wildlife, poor service provided during nightlife in camp site, lack of facility for children and elders are also among the factors that caused dissatisfaction of the tourists.

The finding seems to relate with that of Middleton and Clarke [17] which hold that accommodation unit: hotels, campsites, caravan parks, hostels, guesthouses, etc. will have a direct impact on the level of tourists' satisfaction (Figure 4).

\section{Conclusions}

This study was undertaken to explore tourist satisfaction and service delivery by taking Nech Sar national park as focus of study. The results of the study showed that the attributes which satisfied most tourists are the services provided by NNP right the first time and contact with nature where best reaction was felt by the tourists as a result of the landscape, environment, working hours and the inexpensive costs for the service. On the other hand, the tourist found poor satisfaction as a result of the poor road facilities 
Table 3. Important variables that affect tourist overall satisfaction.

\begin{tabular}{|c|c|c|c|c|c|c|c|c|c|c|c|}
\hline \multirow{3}{*}{ No } & \multirow{3}{*}{$\begin{array}{l}\text { Variables that affect overall tourist } \\
\text { satisfaction which are not related } \\
\text { directly with NNP service performance }\end{array}$} & \multicolumn{10}{|c|}{$\begin{array}{c}\text { Percentage of satisfaction from selected } \\
\text { respondent (152) }\end{array}$} \\
\hline & & \multicolumn{2}{|c|}{ Very low } & \multicolumn{2}{|c|}{ Low } & \multicolumn{2}{|c|}{ Undecided } & \multicolumn{2}{|c|}{ Good } & \multicolumn{2}{|c|}{ Very goo } \\
\hline & & No. & $\%$ & No & $\%$ & No. & $\%$ & No. & $\%$ & No. & $\%$ \\
\hline 1 & $\begin{array}{l}\text { Accommodation hotel selection, } \\
\text { quality service (bed, food, drinks) } \\
\text { \& facility condition }\end{array}$ & 111 & 73 & 41 & 27 & - & - & - & - & - & - \\
\hline 2 & $\begin{array}{l}\text { Cost required and expense that delivered } \\
\text { outside of the park }\end{array}$ & - & - & - & - & 23 & 15.1 & 29 & 19.1 & 100 & 65.8 \\
\hline 3 & $\begin{array}{l}\text { Service performance by tour agent in } \\
\text { itinerary arrangements, auxiliary support } \\
\text { and service delivery (fee paid for the tour) }\end{array}$ & - & - & 89 & 58.5 & 11 & 7.2 & 52.1 & 34.2 & - & - \\
\hline 4 & $\begin{array}{l}\text { Access and opportunity to explore local } \\
\text { area\& contact local culture through } \\
\text { memorable incidents }\end{array}$ & 33 & 21.7 & 54 & 35.5 & 3 & 2 & 52 & 34.2 & 10 & 6.6 \\
\hline 5 & $\begin{array}{c}\text { Access and to opportunity to shopping, } \\
\text { taking photos, purchasing } \\
\text { souvenirs and gifts }\end{array}$ & - & - & 19 & 12.5 & - & - & 51 & 33.5 & 82 & 53.8 \\
\hline 6 & $\begin{array}{l}\text { Opportunity for night life } \\
\text { activities \& attractiveness }\end{array}$ & 8 & 5.3 & 30 & 19.7 & - & - & 78 & 51.3 & 36 & 23.7 \\
\hline 7 & $\begin{array}{l}\text { Tour leaders and drivers professional } \\
\text { \&social skills, character, personal } \\
\text { experience, cleanness and knowledge } \\
\text { for achieving the tour objectives }\end{array}$ & 13 & 8.5 & 55 & 36.2 & 10 & 6.6 & 74 & 48.7 & - & - \\
\hline 8 & The peace and quiet of the destination & - & - & 20 & 13.1 & - & - & 80 & 52.6 & 52 & 34.3 \\
\hline 9 & $\begin{array}{l}\text { The climate and the landscapes of the } \\
\text { destination (natural attractions) }\end{array}$ & - & - & & & & & 52 & 34.2 & 100 & 65.8 \\
\hline 10 & Historic sites or places & & & 152 & 100 & & & & & & \\
\hline 11 & $\begin{array}{l}\text { The presence of recreational } \\
\text { attachment in the context of devoted } \\
\text { sport fan behavior at each destination }\end{array}$ & 22 & 14.4 & 59 & 38.8 & - & - & 71 & 46.8 & - & - \\
\hline 12 & Opportunity to learn and see something & 20 & 13.1 & 13 & 8.5 & 31 & 20.4 & 88 & 57.8 & - & - \\
\hline 13 & $\begin{array}{l}\text { Availability of space on } \\
\text { each destination point }\end{array}$ & - & - & 100 & 65.8 & - & - & 52 & 34.2 & - & - \\
\hline 14 & $\begin{array}{l}\text { Tourism service provider (souvenir } \\
\text { shopper and etc.) on their } \\
\text { responsive, reliability, empathy } \\
\text { and prompt service delivered }\end{array}$ & 83 & 54.6 & 60 & 39.4 & - & - & - & - & - & - \\
\hline & Average result & & 12.7 & & 30.3 & & 3.42 & & 29.7 & & 16.7 \\
\hline
\end{tabular}

inside the park, service offered on the night life at comp site of NNP, and employees' capacity on foreign language communication skill.

This study also indicated that, the most important factors that positively affected the 


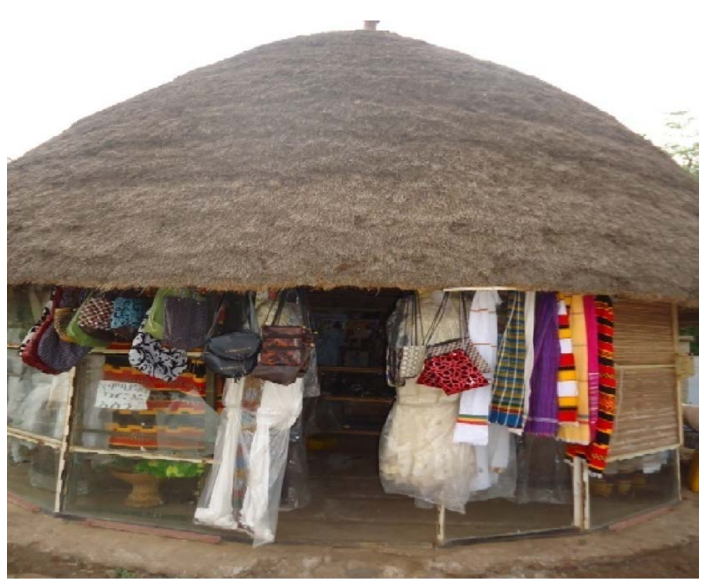

Figure 2. Traditional cloth shopping center in ArbaMinch not far from the park.
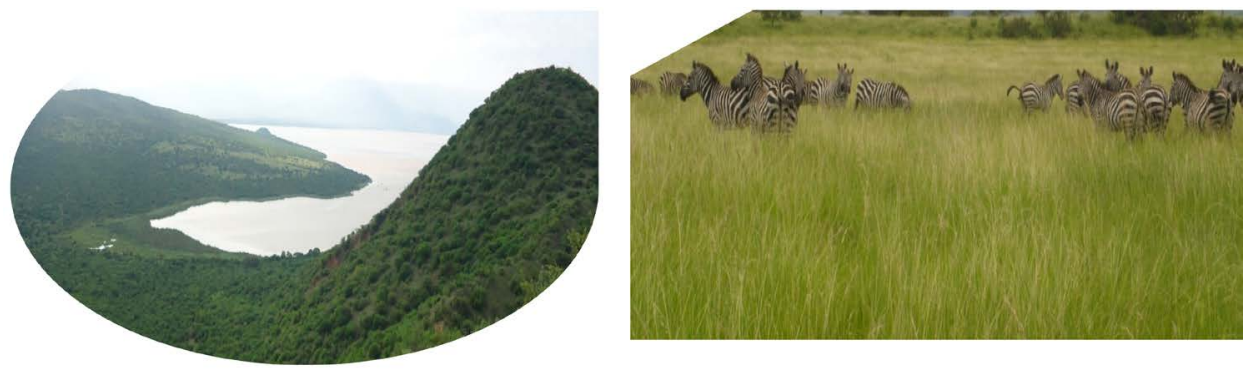

Figure 3. Some of wild animals and attractive landscapes in the park.

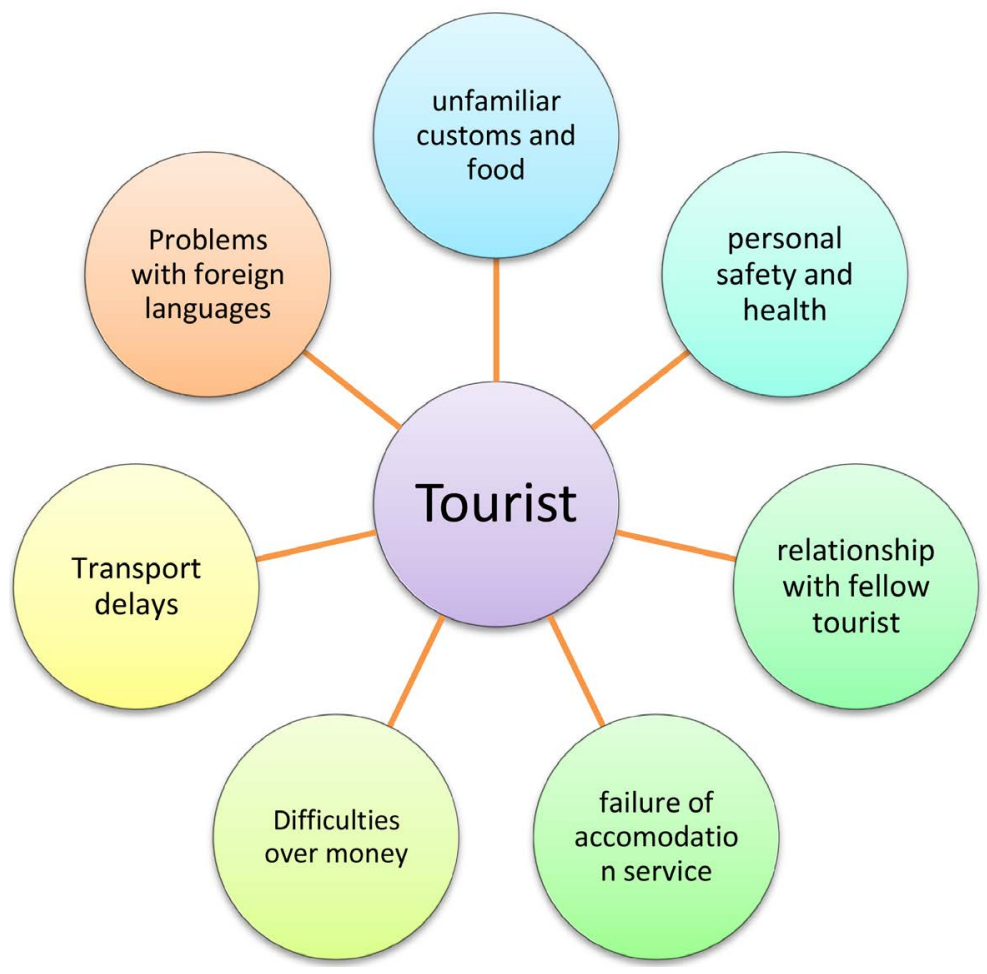

Figure 4. Negative factors which affect tourist satisfaction [16]. 
Table 4. Causes of dissatisfaction.

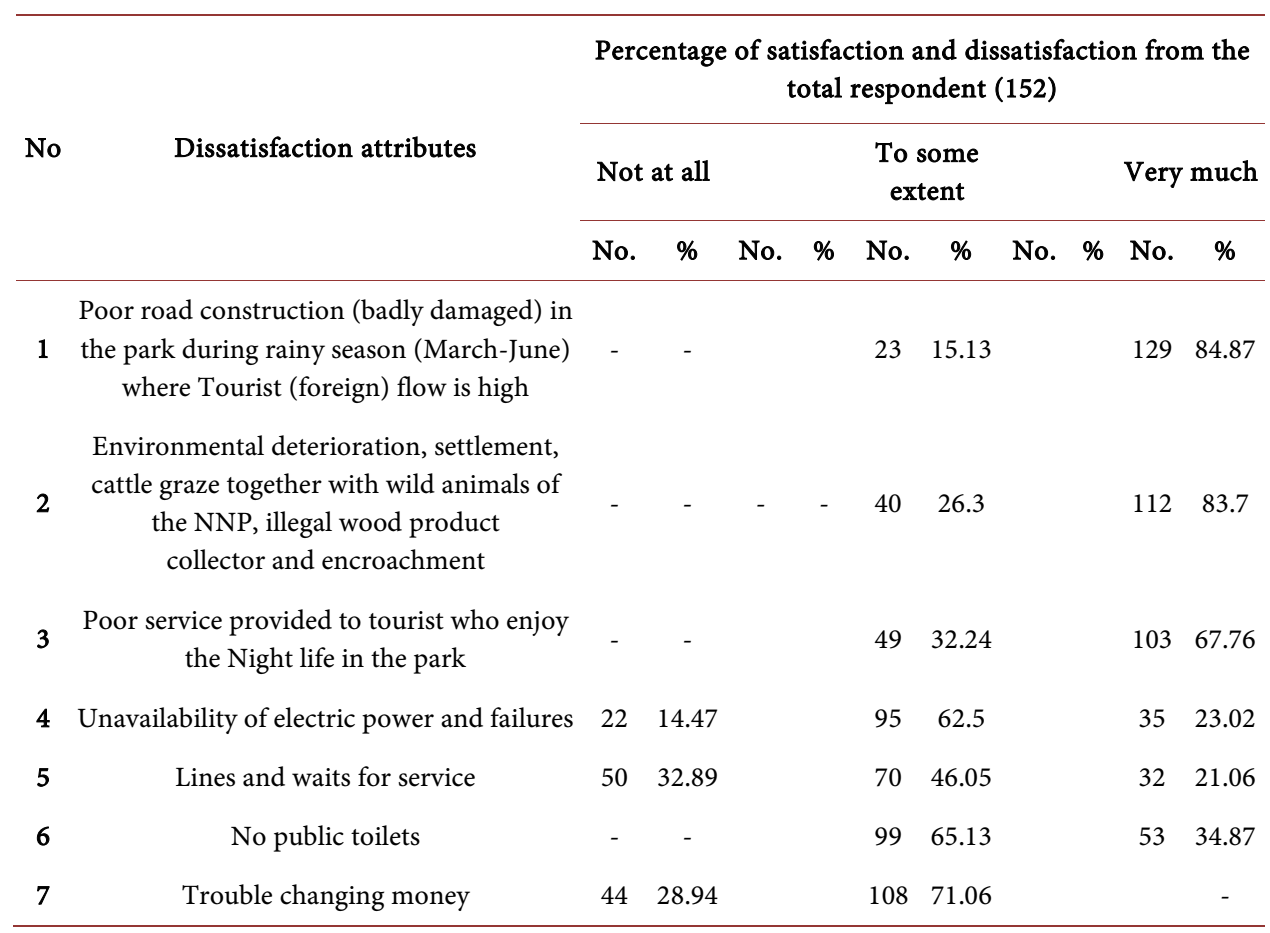

tourist overall satisfaction which are not directly related to service performance of NNP were the peaceful and quite environment to wonder nature. The tourists also got very low satisfaction by the service delivered by hotels, tour agents and access to explore local area and contact local culture through memorable incidence.

The trend of tourist flow to the park is very promising as it shows a steady increase across years and the park is playing its role for the local economic development efforts alongside with environmental development and protection. It is also advisable for policy and decision makers to work on factors which are causing tourist dissatisfaction in the park under study and other similar parks of the country.

\section{References}

[1] Sadeh, S., Asgari, F., Mousavi, L. and Sadeh, S. (2012) Factors Affecting Tourist Satisfaction and its Consequences. Text Road Publications, Iran.

[2] World Bank (2006) Ethiopia: Towards a Strategy for Pro-Poor Tourism Development.

[3] FDRE-PCC (Federal Democratic Republic of Ethiopia, Population Census Commission) (2008) Summary and Statistical Report of the 2007 Population and Housing Census. Addis Ababa, Ethiopia.

[4] Desse, A.M. (2015) Summary of Attractions, Challenges, Research, Management and Partnership Issues on Nech Sar National Park. Arba Minch, Ethiopia.

[5] EWCA (Ethiopian Wildlife Conservation Authority) (2015) Location Map of Nech Sar National Park (on CD), Addis Ababa, Ethiopia.

[6] do Valle, P.O., Silva, J.A., Mendes, J. and Guerreiro, M. (2006) Tourist Satisfaction and Destination Loyalty intention: A Structural and Categorical Analysis. Faculty of Economics, 
University of Algarve, Portugal.

[7] Dorfman, P.W. (1979) Measurement and Meaning of Recreation Satisfaction: A Case Study in Camping. Environment and Behavior, 11, 483-510. https://doi.org/10.1177/0013916579114004

[8] Cardozo, R.N. (1965) An Experimental Study of Customer Effort, Expectation and Satisfaction. Journal of Marketing Research, 2, 244-249. https://doi.org/10.2307/3150182

[9] Hayes, B.E. (1997) Measuring Customer Satisfaction: Survey Design, Use, and Statistical Analysis Methods. ASQC Quality Press, Milwaukee, WI.

[10] Lewis, R. and Booms, B. (1983) The Marketing Aspects of Service Perspectives on Services Marketing. American Marketing Association, Chicago.

[11] Parasuraman, A., Zeithaml, V. and Berry, L. (1988) SERVQUAL-Multiple-Item Scale for Measuring Consumer Perceptions of Service Quality. Journal of Retailing, 64, 12-40.

[12] Lewis, B. and Mitchell, V. (1990) Defining and Measuring the Quality of Customer Service. Marketing Intelligence and Planning, 8, 11-17. https://doi.org/10.1108/EUM0000000001086

[13] Parasuraman, A., Zeithaml, V.A. and Berry, L.L. (1985) A Conceptual Model of Service Quality and Its Implications for Future Research. The Journal of Marketing, 49, No. 4. http://citeseerx.ist.psu.edu/viewdoc/download?doi=10.1.1.470.4027\&rep=rep1\&type=pdf

[14] Gronroos, C. (1990) Service Management and Marketing-Managing Moments of Truth in Service Competition. Lexington Books, Lexington, MA.

[15] Sweeney, J., Johnson, L. and Armstrong, R. (1992) The Effect of Cues on Service Quality Expectation and Services Selection in a Restaurant Setting. Journal of Services Marketing, 6, 15-22. https://doi.org/10.1108/08876049210037122

[16] Bowie, D. and Chang, J.C. (2005) Tourist Satisfaction: A View from a Mixed International Guided Package Tour. Journal of Vacation Marketing, 11, 303-322.

https://doi.org/10.1177/1356766705056628

[17] Middleton, V. and Clarke, J. (2001) Marketing in Travel and Tourism. 3rd Edition, Elsevier, Oxford.

\section{Submit or recommend next manuscript to OALib Journal and we will provide best service for you:}

- Publication frequency: Monthly

- 9 subject areas of science, technology and medicine

- Fair and rigorous peer-review system

- Fast publication process

- Article promotion in various social networking sites (LinkedIn, Facebook, Twitter, etc.)

- Maximum dissemination of your research work

Submit Your Paper Online: Click Here to Submit

Or Contact service@oalib.com 